\title{
MONEY AND INFLATION IN THE EURO AREA: A CASE FOR MONETARY INDICATORS?
}

\author{
Stefan Gerlach \\ Lars E.O. Svensson \\ Working Paper 8025 \\ http://www.nber.org/papers/w8025

\section{NATIONAL BUREAU OF ECONOMIC RESEARCH 1050 Massachusetts Avenue Cambridge, MA 02138} \\ December 2000
}

\begin{abstract}
We thank Juan-Luis Vega for data and helpful comments; Jeffrey Amato, Andreas Fischer, Roberto Golinelli, Reiner König, Glenn Rudebusch, Pierre Sicsic and participants in seminars at the ECB, the Money, Macro and Finance Research Group at LSE, the University of Basel and the University of Bern for useful discussions; Gert Schnabel for research assistance; and Annika Andreasson for secretarial and editorial assistance. The views expressed are our own and not necessarily those of the BIS or the National Bureau of Economic Research.
\end{abstract}

(C) 2000 by Stefan Gerlach and Lars E.O. Svensson. All rights reserved. Short sections of text, not to exceed two paragraphs, may be quoted without explicit permission provided that full credit, including $(\mathbb{C}$ notice, is given to the source. 
Money and Inflation in the Euro Area: A Case for Monetary Indicators?

Stefan Gerlach and Lars E.O. Svensson

NBER Working Paper No. 8025

December 2000

JEL No. E42, E52, E58

\section{ABSTRACT}

This paper studies the relationship between inflation, output, money and interest rates in the euro area, using data spanning 1980-2000. The $P^{*}$ model is shown to have considerable empirical support. Thus, the "price gap" or, equivalently, the "real money gap" (the gap between current real balances and long-run equilibrium real balances), has substantial predictive power for future inflation. The real money gap contains more information about future inflation than the output gap and the Eurosystem's money-growth indicator (the gap between current M3 growth and a reference value). The results suggest that the Eurosystem's money-growth indicator is an inferior indicator of future inflation.

Stefan Gerlach

Bank for International Settlements

CH-4002 Basel

Switzerland

and CEPR

Stefan.Gerlach@bis.org
Lars E.O. Svensson

Institute for International Economic Studies Stockholm University SE-106 91 Stockholm Sweden and NBER, CEPR

Lars.Svensson@iies.su.se 


\section{Introduction}

This paper studies data spanning 1980-2000 on prices, output, money and interest rates in the countries constituting the euro area, and focuses on the question of what role the ECB should attach to broad money in its conduct of policy. It is motivated by two observations. First, the Eurosystem has adopted a monetary policy framework which emphasizes the role of monetary aggregates (see ECB [14]). While it has made clear that monetary targeting would not be appropriate under current conditions (Issing [21]), the Eurosystem's announcements suggest that broad money growth is a major information variable used when setting policy. Second, it is sometimes claimed that the Bundesbank's and the Swiss National Bank's (SNB's) outstanding record of inflation control stemmed from their use of monetary targeting. However, a number of scholars of German monetary policy have argued that the Bundesbank's "pragmatic" monetary targeting was best viewed as monetary targeting in words only, but inflation targeting in deeds. ${ }^{1}$ Similarly, many observers have interpreted the SNB's policy decisions as suggesting that the deviation of the monetary base from target was by no means the sole factor influencing policy. ${ }^{2}$ Furthermore, in December 1999, the SNB [40] officially abandoned monetary targeting, announced a definition of price stability similar to the Eurosystem's, and declared that "[m] onetary policy decisions will be based mainly on an inflation forecast, which will take all relevant indicators into account."

The Eurosystem has announced that it relies heavily on two "pillars" in determining the appropriate level of interest rates. The first of these is a money-growth indicator, defined as the deviation of M3 growth from a reference value, which under normal circumstances is supposed to signal "risks to price stability" (ECB [14]). The second pillar is an inflation forecast, referred to as a "broadly-based assessment of the outlook for future price developments." The prominence given to the money-growth indicator has been criticized, for instance by Svensson [35], on the grounds that it may be a poor predictor of the future path of prices and that instead the second pillar, the inflation forecast, is likely to be considerable more useful in assessing risks to price stability.

Against this background, the paper examines the role of monetary aggregates as indicators of future inflation when gearing policy to maintaining price stability. We are particularly concerned

\footnotetext{
${ }^{1}$ This literature includes Neumann [27], von Hagen [45], Bernanke and Mihov [2], Clarida and Gertler [9], Clarida, Gali and Gertler [7] (note a crucial typo: the coefficient for money supply in Table 1 should be 0.07 instead of 0.7), Laubach and Posen [24], and Bernanke, Laubach, Mishkin and Posen [1].

${ }^{2}$ Rich [31] contains an excellent discussion of Swiss monetary policy since the early 1970s.
} 
by the question of what forms of monetary indicators are useful, if money does indeed play an important role in influencing inflation a year or two ahead. For instance, does the Eurosystem's money-growth indicator provide information about the future course of inflation? If so, is it more informative than a "price gap" or a "real money gap" ?3 We also investigate whether monetary indicators dominate output gaps as information variables for future inflation.

We note from the outset that an unavoidable problem in studying monetary relationships in the euro area is the fact that there is little data from the period after the introduction of the euro on January 1, 1999. One possible reaction to this is to conclude that empirical work had better wait until more data is available. Alternatively, one can construct measures of aggregate money, prices, output and interest rates in the countries forming the euro area for the period before the introduction of the euro, and use these to study the information content of money. ${ }^{4}$ Of course, in doing so one must hope that the dynamic relationships between the data will remain broadly stable even after the introduction of the euro, in defiance of the Lucas critique. In this paper we take this second route, fully recognizing the problems that are implicit in the strategy. ${ }^{5}$

To preview our results, we find that the so-called $P^{*}$ model has substantial empirical support. Thus, the "price gap", or equivalently and in our view preferably ${ }^{6}$ the "real money gap" (defined as the gap between current real money balances and long-run equilibrium real money balances) contains considerable information about the future path of inflation. Furthermore, and perhaps surprisingly, the real money gap has more predictive power than the output gap. These results suggest that the real money gap should be an important information variable for the Eurosystem. Furthermore, we find that while the Eurosystem's money-growth indicator (the gap between current M3 growth and the Eurosystem's reference value) does have some predictive power for future inflation, this information is already embedded in the real money gap. ${ }^{7}$ Thus, the money-growth indicator has no marginal predictive power in the presence of the real money gap.

The paper is structured as follows. Section 2 discusses inflation, output, money and interest

\footnotetext{
3 The role of indicators in monetary policy is discussed in a classic papers by Kareken, Muench and Wallace [23] and Friedman [15]. A recent more general discussion is in Svensson [36, section 3.3]. Svensson and Woodford [39] provide a rigorous analysis of the role of indicators for optimal policy in a model with partial information and forward-looking variables.

${ }^{4}$ Wesche [46] takes this approach and estimates $P^{*}$-models on aggregated data for various European groupings of countries.

${ }^{5}$ A third route is to use U.S. data, on the ground that the Euro area will be a closed economy of similar size as the U.S., and that therefore results about U.S. relations between inflation, interest rates, output and money should be of some relevance for the Euro area. This route is followed in Rudebusch and Svensson [33].

${ }^{6}$ In our view, the concept "real money gap" is preferable because it (1) refers directly to monetary aggregates (which is advantageous in a discussion of the predictive power of monetary aggregates), (2) is consistent with the insight that demand for money is demand for real money, (3) gives a precise meaning to the (somewhat imprecise) notion of "monetary overhang," and (4) lends itself to comparision with the output gap.

7 The issue of the existence of a direct real-money effect on output, argued by Meltzer [25] and Nelson [26], is not examined in this paper.
} 
rates in theory. Section 3 examines the corresponding empirical relations between these variables in euro-area data, including the empirical properties of monetary indicators, especially the Eurosystem's money-growth indicator. Section 4 presents some conclusions.

\section{Inflation and money in theory}

In this section we set out a minimum model of the determination of prices. The model emphasizes the role of monetary factors in the inflation process and consists of an inflation equation and a money-demand equation. In what follows, all variables (except interest rates and time) are in natural logarithms. Logs and interest rates are scaled by one hundred; hence they are measured in percent. Time should be thought of as being measured in quarters.

\subsection{Inflation determination}

The starting point for our analysis is a Phillips curve of the form

$$
\pi_{t+1}=\pi_{t+1, t}^{e}+\alpha_{y}\left(y_{t}-y_{t}^{*}\right)+\alpha_{z} z_{t+1}+\varepsilon_{t+1},
$$

where $\pi_{t} \equiv 4 \Delta p_{t} \equiv 4\left(p_{t}-p_{t-1}\right)$ is the annualized inflation rate in quarter $t, p_{t}$ is the price level, $\pi_{t+1, t}^{e}$ is expectations in quarter $t$ of inflation in quarter $t+1$ (which we specify further below), $y_{t}$ is output, $y_{t}^{*}$ is potential output, $y_{t}-y_{t}^{*}$ is the output gap, $z_{t}$ is any exogenous variable or shift factor (for instance, a supply shock) (we discuss the dating of the exogenous variable further below), and $\varepsilon_{t}$ an iid "cost-push" shock, and where $\alpha_{y}>0$.

In $P^{*}$ models (see Hallman, Porter and Small [19] and Tödter and Reimers [42]), inflation is instead assumed to be governed by

$$
\pi_{t+1}=\pi_{t+1, t}^{e}-\alpha_{p}\left(p_{t}-p_{t}^{*}\right)+\alpha_{z} z_{t+1}+\varepsilon_{t+1},
$$

where $\alpha_{p}>0$. Thus, the $P^{*}$ model replaces the output gap with the negative of the "price gap," $p_{t}-p_{t}^{*}$, as the key determinant of inflation. ${ }^{8}$ Here $p_{t}^{*}$, the long-run equilibrium (LRE) price level, denotes the price level that would result with the current money stock, provided output is at potential and velocity at its long-run equilibrium level. Thus, $p_{t}^{*}$ is defined as

$$
p_{t}^{*} \equiv m_{t}+v_{t}^{*}-y_{t}^{*}
$$

where $m_{t}$ is the money stock (in empirical work typically M2 or M3), $v_{t} \equiv p_{t}+y_{t}-m_{t}$ is velocity, and $v_{t}^{*}$ is the LRE velocity, which we specify further below.

\footnotetext{
${ }^{8}$ Some of the literature has defined the price gap with the opposite sign, as $p_{t}^{*}-p_{t}$.
} 
While the microfoundations of the $P^{*}$ model are not clear (to us, at least), the model has been used to account for the behavior of prices in a number of countries, and is typically seen among proponents for monetary targeting as providing a theoretical rationale for focusing policy deliberations on the behavior of monetary aggregates. ${ }^{9}$ For these reasons, we use the $P^{*}$ set-up here. ${ }^{10}$

Since we focus on the role of monetary aggregates, it is instructive to follow Svensson [37] and express the $P^{*}$ model in terms of the real money gap, $\tilde{m}_{t}-\tilde{m}_{t}^{*}$, where $\tilde{m}_{t} \equiv m_{t}-p_{t}$ is real money balances and

$$
\tilde{m}_{t}^{*} \equiv m_{t}-p_{t}^{*} \equiv y_{t}^{*}-v_{t}^{*}
$$

is LRE real money balances. Since the real money gap is the negative of the price gap,

$$
\tilde{m}_{t}-\tilde{m}_{t}^{*} \equiv\left(m_{t}-p_{t}\right)-\left(m_{t}-p_{t}^{*}\right)=-\left(p_{t}-p_{t}^{*}\right)
$$

we can then write the $P^{*}$ model as

$$
\pi_{t+1}=\pi_{t+1, t}^{e}+\alpha_{m}\left(\tilde{m}_{t}-\tilde{m}_{t}^{*}\right)+\alpha_{z} z_{t+1}+\varepsilon_{t+1}
$$

where $\alpha_{m} \equiv \alpha_{p}>0$. The $P^{*}$ model consequently assigns a crucial role to the real money gap as a predictor of future inflation, analogous to the role of the output gap in traditional Phillips curves. One immediate consequence of this is that, to the extent the $P^{*}$ model accounts for the behavior of inflation, the real money gap, rather than nominal money growth, is the natural indicator of future inflation. We show in the empirical part of the paper that this is the case in the euro-area data we consider.

\subsubsection{Inflation expectations}

To make the inflation equation operational, we need to specify how expectations are formed. For a forward-looking Phillips curve, the rational expectations hypothesis is typically invoked. ${ }^{11}$ For

\footnotetext{
${ }^{9}$ The $P^{*}$ model is used to discuss Bundesbank monetary targeting in Jahnke and Reimers [22], Neumann [27], Tödter and Reimers [42], Tödter and Ziebarth [43] and von Hagen [45]. This may give the impression that the $P^{*}$ model provides some rationale for money-growth targeting, especially since the $P^{*}$ model seems to be part of the Bundesbank's view of the transmission mechanism of monetary policy, see Jahnke and Reimers [22]. Svensson [37] shows that, although the $P^{*}$ model gives a prominent role to monetary aggregates, in particular the "real money gap," it does not provide a rationale for money-growth targeting.

Hallman, Porter and Small [19] and Christiano [6] discuss the performance of the $P^{*}$ model for the U.S.

10 See Meltzer [25], Nelson [26], Rudebusch and Svensson [33], Svensson [34] and Woodford [47] for recent discussions of the role of money in monetary policy and the transmission mechanism.

${ }^{11}$ See Roberts [30] for discussion of alternative Phillips curves. Bernanke and Woodford [3], Clarida, Gali and Gertler [8] and Svensson and Woodford [38] discuss forward-looking Phillips curves with inflation predetermined by one period and given by

$$
\pi_{t+1}=\delta \mathrm{E}_{t} \pi_{t+2}+\alpha_{y} \mathrm{E}_{t}\left(y_{t+1}-y_{t+1}^{*}\right)+\varepsilon_{t+1},
$$
}

where $\delta(0<\delta \leq 1)$ is a discount factor. 
a simple backward-looking Phillips curve, inflation expectations, $\pi_{t+1, t}^{e}$, are normally modelled as being adaptive and given by current and lagged inflation. ${ }^{12}$ In addition to past inflation rates, monetary policy makers' views regarding the acceptable or desirable rate of inflation play an important role in the inflation process by influencing inflation expectations. To model this relationship, we let the expected rate of inflation also depend on the euro-area central banks' average implicit "inflation objective," $\hat{\pi}_{t}$, which we specify further below. This objective, which may be time varying, can be interpreted as the inflation rate policy makers would find appropriate in the near future, but it need not necessarily be interpreted as a formal target. In our econometric work, we model expectations as deviating from the objective according to

$$
\pi_{t+1, t}^{e}=\hat{\pi}_{t+1}+\alpha_{\pi}\left(\pi_{t}-\hat{\pi}_{t}\right)
$$

where $0 \leq \alpha_{\pi} \leq 1$. In this formulation, we may interpret $1-\alpha_{\pi}$ as an index of credibility of the inflation objective. The closer to unity this index is, the more credible is the inflation objective, in the sense of inflation expectations being more influenced by the objective and less influenced by deviations of inflation from the objective.

Before proceeding, it is useful to consider the behavior of inflation in LRE, which we define as a situation in which $\tilde{m}_{t} \equiv \tilde{m}_{t}^{*}, z_{t+1} \equiv 0, \varepsilon_{t+1} \equiv 0$ and $\pi_{t+1, t}^{e}=\hat{\pi}_{t+1}$. From (2.6) and (2.7) we then have that

$$
\pi_{t+1}=\hat{\pi}_{t+1}
$$

Thus, the LRE rate of inflation is given by the central banks' inflation objective.

\subsection{The demand for real money balances}

To operationalize the concept of the real money gap, we must specify the demand for the real money stock. Following the large econometric literature on the demand for money, we assume the following simple, but reasonably flexible and realistic error-correction specification,

$$
\Delta \tilde{m}_{t+1}=\kappa_{0}-\kappa_{m}\left[\tilde{m}_{t}-\kappa_{y} y_{t}+\kappa_{i}\left(i_{t}^{l}-i_{t}\right)\right]-\kappa_{\pi}\left(\pi_{t+1}-\hat{\pi}_{t+1}\right)+\kappa_{1} \Delta \tilde{m}_{t}+\xi_{t+1},
$$

where $i_{t}^{l}$ denotes the yield to maturity on long bonds, $i_{t}$ a short interest rate, $\kappa_{m}, \kappa_{y}, \kappa_{i}>0$ and $\xi_{t}$ is an iid money-demand shock. Since we use a broad monetary aggregate, M3, in the econometric analysis below, it is unrealistic to assume that money is not interest bearing. Thus, we consider

\footnotetext{
${ }^{12}$ Fuhrer [16] and [17], comparing forward- and backward-looking Phillipcs curves for the U.S., finds that a backward-looking Phillips curve cannot be rejected. Rudebusch and Svensson [32], Gerlach and Smets [18], Peersman and Smets [29] and Taylor [41] have recently estimated such backward-looking Phillips curves for U.S. and European data.
} 
the spread between the long and the short interest rate, $i_{t}^{l}-i_{t}$, as measuring the opportunity cost of holding money. This is consistent with the short interest rate being a proxy for the own return on money, and long bond yields capturing the return on the main non-monetary asset. ${ }^{13}$ With the dating of variables in (2.9) and the assumption that inflation is predetermined one quarter, it follows that money demand is also predetermined by one quarter. ${ }^{14}$

Several aspects of this demand function are notable. First, the inclusion of the term $-\kappa_{\pi} \pi_{t+1}$ on the right side of (2.9) allows the adjustment to a long-run equilibrium to be in terms of the change in the real money stock $\left(\kappa_{\pi}=0\right)$ or the nominal money stock $\left(\kappa_{\pi}=1\right)$, or intermediate cases between the two $\left(0<\kappa_{\pi}<1\right)$. Thus, the equation does not impose instantaneous homogeneity of money demand with respect to prices. Second, the term inside the bracket can be interpreted as a long-run money demand equal to

$$
\tilde{m}_{t}=\kappa_{y} y_{t}-\kappa_{i}\left(i_{t}^{l}-i_{t}\right)
$$

where we assume that real money balances are normalized so that there is no constant in (2.10). Third, we define a long-run equilibrium (LRE) as a situation when output equals potential output $\left(y_{t}=y_{t}^{*}\right)$, inflation equals the inflation objective $\left(\pi_{t+1}=\hat{\pi}_{t+1}\right.$, which requires the inclusion of $\kappa_{\pi} \hat{\pi}_{t+1}$ on the right side of (2.9) to eliminate the effect of $\pi_{t+1}$ in LRE), and the interest rate spread equals its LRE value. On the basis of graph 2 below, we assume that the interest rate spread is stationary and that the LRE spread is constant. Thus, the LRE real money balances fulfill

$$
\tilde{m}_{t}^{*}=\kappa_{y} y_{t}^{*}+\kappa^{*}
$$

where $\kappa^{*}$ is a constant, equal to the negative of $\kappa_{i}$ times the LRE spread. ${ }^{15}$

\footnotetext{
${ }^{13}$ In most economies, time deposits constitute a large part of M3 and act as a buffer stock when funds are shifted in to, and out of, M3. Since time deposits are typically remunerated at rates close to interbank rates, short rates are a good proxy for the own return on broad monetary aggregates.

14 See Browne, Fagan and Henry [4] for a survey of European money-demand equations. A similar moneydemand equation for M2, although with the short interest rate being the opportunity cost of holding money and without the inflation term on the right hand side, is estimated on U.S. data and used to discuss monetary targeting in Rudebusch and Svensson [33].

${ }^{15}$ This is consistent with defining the short and long LRE nominal interest rates, $i_{t}^{*}$ and $i_{t}^{l *}$, as $i_{t}^{*} \equiv r^{*}+\hat{\pi}_{t+1}$ and $i_{t}^{l *} \equiv r^{l *}+\hat{\pi}_{t+1}$, where $r^{*}$ and $r^{l *}$ are constant short and long LRE real interest rates, and both short- and long-run inflation expectations equal the current inflation objective. Then,

$$
\kappa^{*}=-\kappa_{i}\left(i_{t}^{l *}-i_{t}^{*}\right)=-\kappa_{i}\left(r^{l *}-r^{*}\right) .
$$

Furthermore, in a LRE, it follows that $\Delta \tilde{m}_{t}^{*}=\kappa_{y} \Delta y_{t}^{*}$. Assuming that $\Delta y_{t}^{*}$, the trend growth of potential output, is constant and equal to $\Delta y^{*}$, substituting this and $\pi_{t+1}=\hat{\pi}_{t+1}$ into $(2.9)$, it follows that the parameter $\kappa_{0}$ is constant and fulfills

$$
\kappa_{0}=\left(1-\kappa_{1}\right) \kappa_{y} \Delta y^{*} .
$$
}


It follows that LRE velocity, $v_{t}^{*} \equiv y_{t}^{*}-\tilde{m}_{t}^{*}$, referred to in (2.3) and (2.4), is given by

$$
v_{t}^{*}=\left(1-\kappa_{y}\right) y_{t}^{*}-\kappa^{*}
$$

\section{Inflation and money in euro-area data}

Having reviewed out model, we next discuss the data, our estimation strategy and the results.

\subsection{The data}

As noted above, since the euro was launched at the beginning of 1999, there is little data available. In order to carry out the empirical analysis, we therefore use aggregate data for the euro area before the introduction of the euro. The data on output, money and short and long interest rates are somewhat revised data from Coenen and Vega [10]. They were also updated using the ECB's Monthly Bulletin. Moreover, we construct measures of euro-wide consumer prices and of the energy component in the consumer price index, and a measure of the output gap. ${ }^{16}$ Potential output is computed by subtracting the output gap from output. While the data set starts in 1980:1 and ends in 2000:2, estimation starts typically in 1981:4 to compute growth rates and to allow for sufficient lags in the regression equations.

To explore the relationship between the variables, graph 1 plots inflation and nominal money growth measured over four quarters, $\Delta_{4} p_{t}$ and $\Delta_{4} m_{t} .{ }^{17}$ The graph shows that the inflation rate fell sharply from about $11 \%$ per annum in the early 1980 s to about $2 \%$ in 1986 , then rose to about $5 \%$ in early 1992, after which it gradually declined and fell to $.8 \%$ in the end of 1998 before rising above $2 \%$ in 2000 . Moreover, the rate of money growth fell from $12 \%$ in late 1982 to $3.6 \%$ in 1997 , before accelerating to almost $6 \%$ in the beginning of 2000 . While there is a gradual decline in both variables over the sample period, the bivariate relationship between the two variables does not appear very tight. ${ }^{18}$ Of course, this is not necessarily surprising, since the graph disregards changes in real money growth, which would tend to obscure the relationship

\footnotetext{
16 After 1995:1, the official HICP and the energy component thereof are used. For the earlier period we constructed euro-wide consumer and energy price indices by weighting the growth rates of national price indices, using as weights nominal GDP expressed in common currency. Annual output-gap data were taken from the OECD, and were interpolated to obtain quarterly data points. In addition, oil prices were converted into euro (for use as instruments for the Hausman test) using a synthetic exchange rate.

17 We let $\Delta_{4} x_{t} \equiv x_{t}-x_{t-4}$ for any variable $x$.

${ }^{18}$ ECB [13, Chart 4] presents a variant of graph 1 which gives the impression of a somewhat tighter correlation between money growth and inflation. In that variant, money growth is leaded by 6 quarters and 4-quarter money growth and inflation is smoothed by 8-quarter moving averages. To our knowledge, this is the only empirical evidence the Eurosystem has provided to date in favor of its money-growth indicator.
} 
between money growth and inflation. ${ }^{19}$ In graph 2 we show the behavior of the short and long interest rates; these also fall gradually over time. All-in-all, all the nominal variables illustrate the gradual disinflation achieved in the euro area.

To get a clearer view of the role of money in the inflation process, we next turn to the estimation of the empirical model.

Graph 1

Inflation and money growth

(4-quarter, \%/yr)

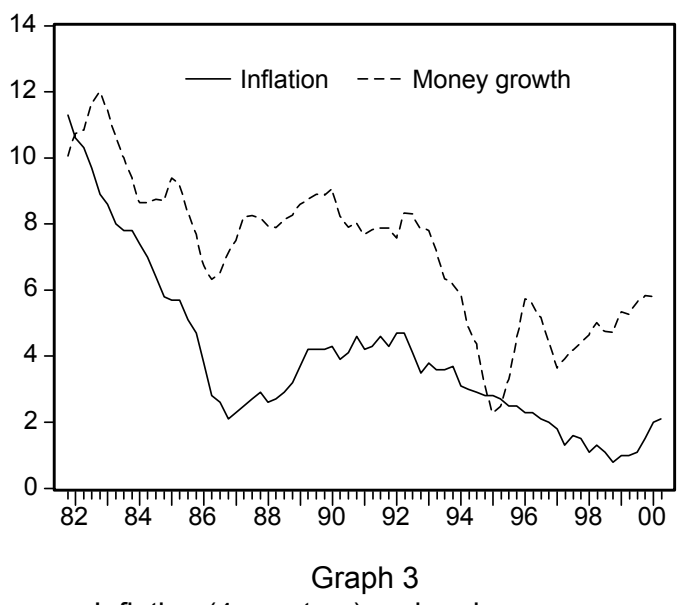

Inflation (4-quarters) and real money gap $(\% / y r$ and $\%)$

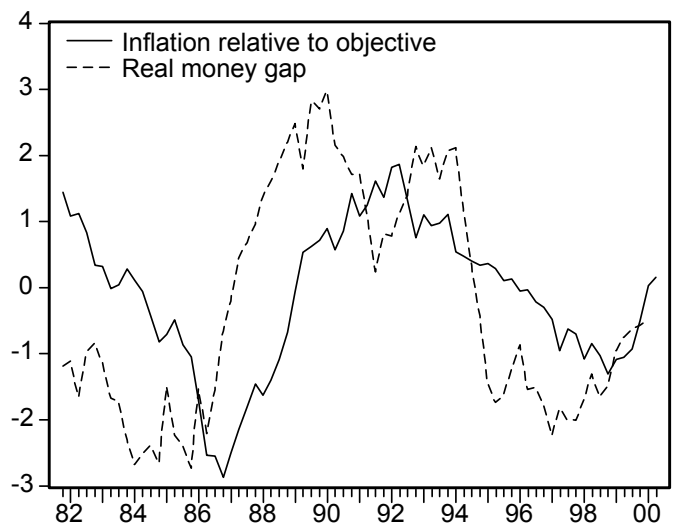

Graph 2

Short and long interest rates

$(\% / y r)$

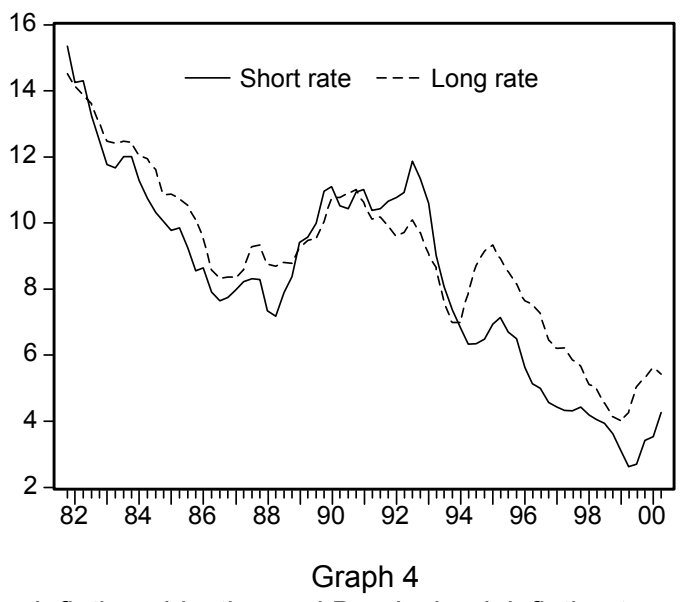

Inflation objective and Bundesbank inflation target $(\% / y r)$

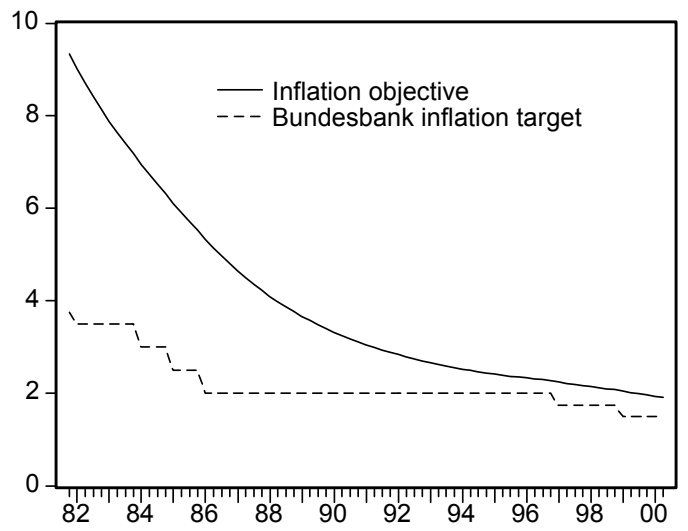

\footnotetext{
${ }^{19}$ Note that, as discussed in Rudebusch and Svensson [33], the relation between inflation and nominal money growth can be illuminated by the identity

$$
\Delta_{4} p_{t} \equiv \Delta_{4} m_{t}-\Delta_{4} \tilde{m}_{t}
$$

where $\Delta_{4} \tilde{m}_{t}$ is 4-quarter real money growth. With an empirical money-demand equation like (2.9), real money growth will not be stable. This will reduce the correlation between inflation and nominal money-growth.
} 


\subsection{Inflation and the inflation objective}

As a preliminary step, it is useful to consider the behavior of inflation. There is little doubt that the decline of inflation has largely been due to the growing commitment on the part of monetary policy makers in the euro area to achieve and maintain low inflation. The gradual decline in inflation can therefore be interpreted as corresponding to a fall in the average (implicit) inflation objective, $\hat{\pi}_{t}$, of the central banks in the euro area.

Since, as assumed in (2.7), the implicit inflation objective influences inflation by affecting inflation expectations, we need to model the evolution over time of the inflation objective. This is not a trivial exercise. To do so, we start from the observation that a main purpose of the European Monetary System, which was founded in 1979, was to facilitate for its members to reduce their inflation rates to levels similar to that in Germany. While the Bundesbank never adopted a formal inflation target, an implicit inflation target (referred to as "unavoidable inflation", a "price norm" or a "medium-term price assumption" - played an integral part in the computation of its monetary target. Below we refer to this for simplicity as Bundesbank's inflation target. Moreover, we assume that the long-run inflation objective of the central banks in the euro area was to reduce inflation to the level given by the Bundesbank's inflation target. Of course, with the average inflation rate in the euro area about 8 percentage points above the Bundesbank's inflation target in the early 1980s, it was clear that the disinflation had to be gradual. In line with this, we assume that the euro-area inflation objective in quarter $t, \hat{\pi}_{t}$, equals actual euro-area 4-quarter inflation in 1981:1 and thereafter converges to Bundesbank's inflation target, $\pi_{t}^{b}$, according to

$$
\hat{\pi}_{t+1}-\pi_{t+1}^{b}=\gamma\left(\hat{\pi}_{t}-\pi_{t+1}^{b}\right)
$$

where $\gamma(0 \leq \gamma \leq 1)$ is inversely related to the speed of convergence.

To operationalize (3.1), we need to make an assumption about the size of $\gamma$. To do so, let $T$ denote the "half-life" of the deviation between the two inflation objectives, that is, the number of quarters it takes to reduce an initial deviation between $\hat{\pi}_{t}$ and $\pi_{t}^{b}$ to a half. Any assumption regarding $T$ has then an implication for $\gamma$, since the two are related by to the formula $\gamma=.5^{1 / T} .{ }^{20}$ Thus, the problem of selecting $\gamma$ can be given an economic content. In the empirical work reported below, we set $T=12$ quarters, which implies that $\gamma=.944$. Since this assumption of the half-life of deviations is arbitrary, we have examined the sensitivity of our

\footnotetext{
${ }^{20}$ We have $\gamma^{T}=0.5$, which results in $\gamma=0.5^{1 / T}$.
} 
results to alternative hypothesis about $T$. Assuming $T=8$ or 16 quarters (implying $\gamma$ equal to .917 or .958 , respectively) has no material impact on the results. Graph 4 shows the resulting inflation objective and the Bundesbank's inflation target. ${ }^{21}$

\subsection{Estimating the model}

Fitting the model entails estimating the inflation equation, (2.6), the weight the public attaches to the deviation of inflation from the objective in forming expectations of the future rate of inflation, (2.7), the money-demand equation, (2.9) and the LRE money demand, (2.11). We fit the inflation and money-demand equations individually using OLS and also as a system using SURE. Since we use mainly pre-1999 data, but are interested in the determination of inflation in the period after establishment of the euro, we find it natural to perform the estimation on data ending in 1998:4, and use the data 1999:1-2000:2 to study the model's out-of-sample performance and to test for structural breaks.

\subsubsection{Estimating $\kappa_{y}$}

In order to estimate $\tilde{m}_{t}^{*}$ in $(2.11)$, we need to know the long-run income elasticity of money demand, $\kappa_{y}$. The long-run income elasticity can be thought of as a cointegration parameter. To estimate it, we follow the Engle and Granger [11] approach, estimate it separately in a first step, then use the resulting estimate in the subsequent regressions.

Thus, we estimate (2.11) separately with OLS. The resulting equation is (1981:4-1998:4),

$$
\tilde{m}_{t}=1.51 y_{t},
$$

(the constant and the OLS standard error are not reported). ${ }^{22}$ We then treat 1.51 as the true value of $\kappa_{y}$, and calculate $\tilde{m}_{t}^{*}$ accordingly.

\subsubsection{The real money gap}

Graph 3 displays our estimate of the real money gap, $\tilde{m}_{t}-\tilde{m}_{t}^{*}$, together with the deviation of inflation measured over four quarters from the inflation objective measured over the same

\footnotetext{
${ }^{21}$ The source of Bundesbank's implicit inflation target through 1998:4 is Bofinger [5], except for 1985 for which we use 2.5\% (see von Hagen [45]). We assume that the inflation target equals 1.5\% per year from 1999:1.

${ }^{22}$ The OLS standard error (which is inconsistent when the variables are nonstationary) is .02. For comparison purposes, we also estimated $\kappa_{y}$ by performing a Johansen test for cointegration on a system consisting of $\tilde{m}_{t}$ and $y_{t}$. After first testing for lag length and the importance of a time trend, we estimated a VAR(3) without a time trend on data spanning 1981:2-1998:4. Both the trace and the maximum eigenvalue tests rejected the hypothesis of no cointegrating vector, but not the hypothesis of at most one cointegrating vector, at the $5 \%$ level. Allowing for one cointegrating relationship, we estimate $\kappa_{y}=1.51$, with a standard error of .03.
} 
time horizon, $\Delta_{4} p_{t}-\Delta_{4} \hat{p}_{t}$. (Here $\hat{p}_{t} \equiv \hat{p}_{0}+\sum_{j=1}^{t} \hat{\pi}_{t+j} / 4$ denotes the price level associated with the inflation objective, so $\Delta_{4} \hat{p}_{t} \equiv \hat{p}_{t}-\hat{p}_{t-4} \equiv \sum_{j=0}^{3} \hat{\pi}_{t-j} / 4$ denotes a four-quarter moving average of the inflation objective; recall that $\hat{\pi}_{t}$ is measured in percent per annum.) The graph shows that both variables evolve in much the same way over time. Moreover, and perhaps more interestingly, the real money gap appears to move somewhat before the rate of inflation, suggesting that it may be useful for predicting future inflation.

\subsubsection{Inflation}

We combine (2.6) and (2.7) into the inflation equation to be estimated,

$$
\pi_{t+1}-\hat{\pi}_{t+1}=\alpha_{\pi}\left(\pi_{t}-\hat{\pi}_{t}\right)+\alpha_{m}\left(\tilde{m}_{t}-\tilde{m}_{t}^{*}\right)+\sum_{\tau=0}^{3} \alpha_{q \tau} \Delta q_{t+1-\tau}+\varepsilon_{t+1},
$$

where we have also added four lags of inflation in energy prices, $\Delta q_{t+1}$ among the regressors. (Hence, they correspond to the exogenous variable $z_{t+1}$ in (2.6)). The reason for doing so is that energy price movements typically account for a large fraction of the short-term variability of CPI inflation. Since such price movements are largely exogenous and not easily undone by monetary policy measures, we control for their impact by including the current and three lagged values among the regressors. A further reason for including energy prices among the regressors is that not doing so would lead to omitted variables bias. Moreover, and more importantly, it would increase the variance of the residuals and worsen the fit of the equation. This is of particular concern in our case since it is more difficult to reject the hypothesis of parameter constancy, and the confidence bands for out-of-sample forecasts are larger and thus less stringent, in a poorly fitting model.

Table 1, column 1, reports the OLS estimate of this equation, using the inflation objective corresponding to a half-life of deviations of 12 quarters $(T=12)$. The coefficient on the real money gap, $\alpha_{m}$, is substantial and significant at a $1 \%$ level (the $p$-value is less than .0001). The point estimate of $\alpha_{\pi}$ (which captures the importance lagged inflation for expected future inflation) is .34, which implies that the weight of the inflation objective in expected inflation is .66. The rate of change of energy prices are also highly significant. Overall the equation appears to fit quite well.

Since the contemporaneous change in energy prices that appear among the regressors is highly significant, it may be argued that the estimates may be subject to simultaneity bias of unknown magnitude. To guard against this possibility, we conduct a Hausman test ([20]). Using 
the current and four lagged levels of oil prices expressed in euros, we obtain a p-value of $0.44 .^{23}$ Thus, we do not reject the hypothesis that energy prices are exogenous.

Table 1. Inflation

1981:4-1998:4

\begin{tabular}{c|cccccc}
\hline Equation & $(1)$ & $(2)$ & $(3)$ & $(4)$ & $(5)$ & $(6)$ \\
Estimation & OLS & SURE & OLS & OLS & OLS & OLS \\
\hline$\pi_{t}-\hat{\pi}_{t}$ & $.354^{* *}$ & $.385^{* *}$ & $.351^{* *}$ & $.437^{* *}$ & $.464^{* *}$ & $.390^{* *}$ \\
& $(.095)$ & $(.089)$ & $(.098)$ & $(.103)$ & $(.103)$ & $(.103)$ \\
$\tilde{m}_{t}-\tilde{m}_{t}^{*}$ & $.284^{* *}$ & $.281^{* *}$ & $.285^{* *}$ & - & - & - \\
& $(.057)$ & $(.054)$ & $(.092)$ & & & \\
$y_{t}-y_{t}^{*}$ & - & - & .028 & $.219^{* *}$ & - & $.188^{*}$ \\
& & & $(.087)$ & $(.075)$ & & $(.075)$ \\
$\Delta_{4} m_{t}-\Delta_{4} m_{t}^{*}$ & - & - & -.031 & - & $.207^{*}$ & $.162^{*}$ \\
& & & $(.099)$ & & $(.084)$ & $(.083)$ \\
\hline$\Delta q_{t+1}$ & $.223^{* *}$ & $.242^{* *}$ & $.233^{* *}$ & $.271^{* *}$ & $.246^{* *}$ & $.251^{* *}$ \\
& $(.066)$ & $(.062)$ & $(.067)$ & $(.072)$ & $(.075)$ & $(.072)$ \\
$\Delta q_{t}$ & .002 & -.011 & .003 & -.012 & -.016 & .000 \\
& $(.073)$ & $(.068)$ & $(.074)$ & $(.081)$ & $(.082)$ & $(.079)$ \\
$\Delta q_{t-1}$ & $-.199^{* *}$ & $-.205^{* *}$ & $-.197^{* *}$ & $-.203^{* *}$ & $-.218^{* *}$ & $-.206^{* *}$ \\
& $(.068)$ & $(.064)$ & $(.069)$ & $(.075)$ & $(.077)$ & $(.074)$ \\
$\Delta q_{t-2}$ & $.283^{* *}$ & $.264^{* *}$ & $.277^{* *}$ & $.232^{* *}$ & $.275^{* *}$ & $.260^{* *}$ \\
& $(.057)$ & $(.053)$ & $(.059)$ & $(.063)$ & $(.065)$ & $(.063)$ \\
\hline $\bar{R}^{2}$ & .71 & .71 & .70 & .65 & .63 & .66 \\
$\mathrm{SEE}$ & .72 & .72 & .73 & .80 & .81 & .78 \\
$\mathrm{DW}$ & 2.20 & 2.28 & 2.19 & 2.20 & 2.20 & 2.20 \\
\hline
\end{tabular}

Note: Standard errors in parenthesis. ${ }^{*} / * *$ denotes significance at the $5 \% / 1 \%$ level. The constant is not reported.

We also estimate our preferred specification of the inflation equation together with the money demand function (see below), using Seemingly Unrelated Regression techniques (SURE). The results in column 2 are very similar to those in column one-although the standard errors are somewhat smaller - and we therefore do not refer to them further. ${ }^{24}$

The finding that the real money gap has substantial predictive power for future inflation in the euro-area data considered is encouraging and raises the question whether it is more

\footnotetext{
${ }^{23}$ The R-square in the first-step regression is 0.74 and the p-value for a test of the hypothesis that all regressors are zero is .000 . The result of nonsignificance of the Hausman specification test is not sensitive to the inclusion of the current level of oil prices or the exact lag length.

${ }^{24}$ The correlation coefficient for the error terms in the inflation and money-demand equations is -.28 .
} 
informative than the output gap and Eurosystem's money-growth indicator, both of which might contain information about the future path of prices. To address this question, we specify the money-growth indicator as $\Delta_{4} m_{t}-\Delta_{4} m_{t}^{*}$, the four-quarter growth of nominal M3, $\Delta_{4} m_{t}$, less a reference value for four-quarter money growth, $\Delta_{4} m_{t}^{*}$. The Eurosystem, following Bundesbank, specifies the reference value as the sum of an inflation target and a forecast of potential output growth, less a forecast of the velocity trend (see ECB [12] and [14]). Thus, we can interpret

$$
\Delta m_{t+4 \mid t}^{*} \equiv \Delta_{4} \hat{p}_{t+4}+\Delta_{4} y_{t+4 \mid t}^{*}-\Delta v_{t+4 \mid t}^{*}
$$

as a reference value for nominal money growth for the next four quarters, involving the fourquarter inflation objective and four-quarter forecast of potential output and LRE velocity. In the regressions below, we define the reference value as

$$
\Delta_{4} m_{t}^{*} \equiv \Delta_{4} \hat{p}_{t}+\Delta_{4} y_{t}^{*}-\Delta_{4} v_{t}^{*}
$$

involving the realized (estimated) values of potential output and LRE velocity.

Table 1, column 3, shows an OLS estimate of the inflation equation, (3.2), where the output gap, $y_{t}-y_{t}^{*}$, and the money-growth indicator, $\Delta_{4} m_{t}-\Delta_{4} m_{t}^{*}$, have been added as explanatory variables. Strikingly, the parameter estimates for the real money gap is unaffected by the inclusion of the other two variables and remain highly significant. By contrast, the parameters on the output gap and the money-growth indicator are both numerically small and insignificant. Furthermore, the adjusted R-square falls from .71 to .70. Thus, it appears that neither the output gap nor the money-growth indicator contains any marginal information for future inflation beyond that contained in the real money gap, current inflation and energy-price changes.

To further explore the information content of the output gap and the money-growth indicator, columns 4 and 5 of table 1 show regressions using either the output gap or the money-growth indicator as the key forcing variable for inflation. The output gap is then significant at the $1 \%$ level and the money-growth indicator at the $5 \%$ level. Moreover, the adjusted R-square falls to .64 and .63 , respectively. Since both variables are individually significant, we include both of them. The results in column (6) indicate that both are significant.

From the above analysis we conclude that, while the output gap and the money-growth indicator both contain information about the future course of inflation, that information is embodied in the real money gap which thus appears to be a superior information variable for future inflation. This conclusion is supported by table 2, which shows that the correlations between the real money gap, the output gap and the money-growth indicator are sizeable. In 
particular, the correlation between the real money gap and the money-growth indicator is .72 . Thus, one interpretation of the results in column 5 is that the money-growth is but a proxy for the real money gap (since column 3 indicates that there is no additional information in the money-growth indicator).

Table 2. Correlations

1981:4-1998:4

\begin{tabular}{r|ccc}
\hline & Real money gap & Output gap & Money-growth indicator \\
\hline Real money gap & 1.00 & .64 & .71 \\
Output gap & & 1.00 & .33 \\
Money-growth indicator & & & 1.00 \\
\hline
\end{tabular}

\subsubsection{Money demand}

Column 1 in table 3 provides OLS estimates of the money-demand equation, (2.9). ${ }^{25}$ The results show that the coefficient on the error-correction term, $\kappa_{m}$, is significant, as is the total coefficient, $\kappa_{m} \kappa_{i}$, on the interest rate spread. Thus, an increase in the long interest rate reduces the demand for money, while an increase in the short interest rate, which we take to measure the own return on money, increases money demand. The coefficient on the negative of the deviation between inflation and the inflation objective, $\kappa_{\pi}=.17$, is also significant, implying that the adjustment to the long-run money demand is mostly in terms of the change in real rather than nominal money. Overall, the OLS estimate of the money-demand function seems quite good. Moreover, the parameter estimates are virtually unaffected when the equation is reestimated together with the inflation equation using SURE (see column 2).

\footnotetext{
${ }^{25}$ Note that, by our assumption of inflation being predetermined, the inclusion of $\pi_{t+1}-\hat{\pi}_{t+1}$ among the dependent variables does not introduce any simultaneity bias.
} 
Table 3. Money demand

1981:4-1998:4

\begin{tabular}{c|cc}
\hline $\begin{array}{c}\text { Equation } \\
\text { Estimation }\end{array}$ & $(1)$ & $(2)$ \\
\hline$\tilde{m}-\kappa_{y} y_{t}$ & $-.073^{* *}$ & $-.075^{* *}$ \\
& $(.023)$ & $(.021)$ \\
$i_{t}^{l}-i_{t}$ & $-.135^{* *}$ & $-.117^{* *}$ \\
& $(.041)$ & $(.039)$ \\
$\pi_{t}-\hat{\pi}_{t}$ & $-.168^{* *}$ & $-.139^{* *}$ \\
& $(.032)$ & $(.031)$ \\
$\Delta \tilde{m}_{t}$ & $.384^{* *}$ & $.410^{* *}$ \\
& $(.083)$ & $(.079)$ \\
\hline $\bar{R}^{2}$ & .52 & .51 \\
$\mathrm{SEE}$ & .31 & .31 \\
$\mathrm{DW}$ & 2.17 & 2.33 \\
\hline $\mathrm{Note}$ Stan
\end{tabular}

Note: Standard errors in parenthesis. */

denotes significance at the $5 \% / 1 \%$ level.

\subsection{Out-of-sample prediction}

Our model has been estimated for the sample 1981:4-1998:4. To explore whether it is stable following the introduction of the euro in January 1999, we construct one-quarter-ahead out-ofsample forecast for inflation, $\pi_{t}-\hat{\pi}_{t}$, and real money growth, $\Delta \tilde{m}_{t}$, for 1999:1-2000:2, using the OLS estimates of the two equations. However, since it is arguably more interesting to see what these forecasts implies for 4-quarter inflation, $\Delta_{4} p_{t}$, and 4-quarter nominal money growth, $\Delta_{4} m_{t}$, we present the results in terms of these magnitudes. The results are displayed in graphs 5 and 6 , where the vertical lines show the beginning of the out-of-sample period, the solid lines show the actual outcome, the short-dashed lines show the predictions of the model, and longdashed lines show 95 percent confidence intervals. We interpret the result as suggesting that our models for inflation and money growth are both stable out-of-sample. It is notable that the predictions from the inflation equation are quite good even in late 1999, when inflation increased sharply.

To more formally assess the stability of the two equations, we also perform Chow forecast tests for a break at 1999:1, obtaining a p-value of .52 for the inflation equation and .59 for the money demand function. Thus, these test support the hypothesis that the equations are stable. 
Graph 5

Graph 6

Out-of-sample forecasts of 4-quarter inflation $(\% / y r)$

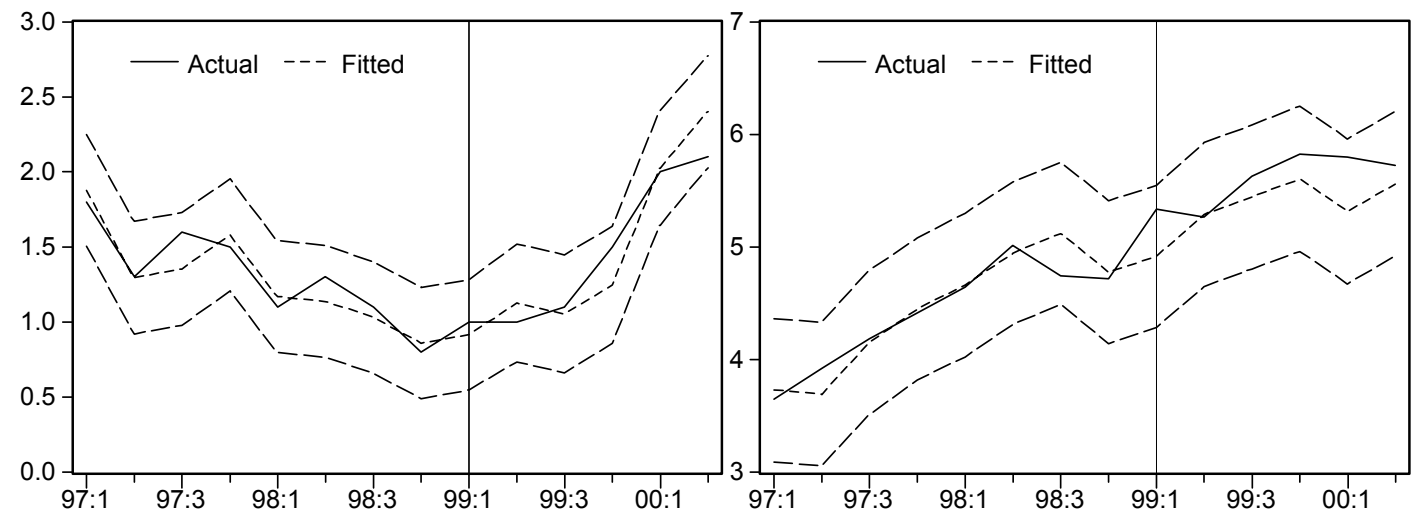

\subsection{Granger-causality tests}

To more informally assess the information content of the different variables, we conduct bivariate Granger-causality tests between inflation deviations, $\pi_{t}-\hat{\pi}_{t}$, the real money gap, $\tilde{m}_{t}-\tilde{m}_{t}^{*}$, the output gap, $y_{t}-y_{t}^{*}$ and the money-growth indicator, $\Delta_{4} m_{t}-\Delta_{4} m_{t}^{*}$, for 2-8 lags. Since the results did not appear sensitive to the choice of lag length, in table 4 we report indicative results assuming a lag length of 6 .

The results indicate that the real money gap Granger-causes inflation deviations. Indeed, the null hypothesis of no Granger-causality is consistently rejected for all lags below the $1 \%$ significance level. There is also evidence that the output-gap Granger-causes inflation deviations, although not as strong. For some lags (other than 6) the null hypothesis is rejected at $5 \%$ significance levels.

Importantly, there is strong indication that the money-growth indicator does not Grangercause inflation deviations. In fact, the null hypothesis of no Granger-causality cannot be rejected at conventional significance levels at any lag. This result is fully consistent with the Grangercausality tests in Trecroci and Vega [44], who also demonstrate that the money-growth indicator does not Granger-cause inflation.

Furthermore, there is strong indication that the real money gap and the output gap Grangercause the money-growth indicator, whereas the reverse is not true. 
Table 4. Granger-causality tests

1982:3-1998:4, 6 lags

\begin{tabular}{r|cc}
\hline Null Hypothesis & Obs & Prob \\
\hline Real money gap does not Granger-cause inflation deviation & 66 & .001 \\
Output gap does not Granger-cause inflation deviation & 66 & .088 \\
Money-growth indicator does not Granger-cause inflation deviation & 66 & .423 \\
Real money gap does not Granger-cause money-growth indicator & 66 & .008 \\
Output gap does not Granger-cause money-growth indicator & 66 & .006 \\
Money-growth indicator does not Granger-cause real money gap & 66 & .520 \\
Money-growth indicator does not Granger-cause output gap & 66 & .611 \\
\hline
\end{tabular}

The results from these Granger causality test supports our earlier finding that the real money gap is a useful indicator of future inflation. While the output gap also is informative about the evolution of inflation, it is less so than the real money gap. Finally, the money-growth indicator does not seem to contain any useful information for future inflation. Overall, we interpret these results as urging caution in employing the money-growth indicator as an information variables for risks to price stability.

\section{Conclusions}

This paper provides a preliminary study of the determination of inflation and the role of monetary indicators in the euro area, using reconstructed data for 1998-2000. A main finding is that the $P^{*}$ model, in which the gap between the current price level and long-run equilibrium price level is the main determinant of future inflation, has substantial empirical support. As in Svensson [37], given the emphasis on monetary indicators and aggregates, we prefer to express the $P^{*}$ model in terms of the real money gap (the gap between the real money stock and the long-run equilibrium real money stock), which is identical to the negative of the price gap. Thus, we find that the real money gap has substantial predictive power for future inflation. It follows that the real money gap should be an important indicator of future inflation for the Eurosystem.

We have also examined the indicator properties for future inflation of the output gap and the Eurosystem's money-growth indicator (the gap between current M3 growth and the Eurosystem's reference value). Surprisingly, the output gap seems to have less predictive power for future inflation than the real money gap. Although the output gap seems to Granger-cause inflation, it does not seem to contain any information not already contained in the real money gap.

Less surprisingly (given earlier theoretical and empirical work), the performance of the Eu- 
rosystem's money-growth indicator is inferior to that of the other two variables. In bivariate Granger-causality tests, the money-growth indicator does not seem to Granger-cause future inflation. Furthermore, it does not contain any marginal information beyond that already contained in the real money gap and the output gap. To the extent the money-growth indicator contains any information for future inflation, it may be exclusively in its capacity as a proxy for the real money gap and/or the output gap. Thus, we find little empirical support for the prominent role the Eurosystem has assigned for its money-growth indicator.

Moreover, as argued theoretically in Svensson [34], [35] and [37] and demonstrated empirically in Rudebusch and Svensson [33], but counter to much conventional wisdom, the lack of predictive power of the money-growth indicator does not depend on the existence of stable short-run or long-run money-demand functions. In the present paper, the inferior performance of the money-growth indicator occurs in spite of well-behaved estimated short-run and long-run moneydemand functions.

In interpreting these results, several caveats need to be kept in mind. First, our empirical results may be sensitive to the exact choice of data. The way the synthetic euro-area data has been constructed may matter, and it is possible that other measures of the output gap are more informative about future inflation than the one used here. Second, the real money gap and the money-growth indicator share with the output gap the dependence on estimates of potential output, which are notoriously difficult and uncertain. Third, calculations of the real money gap and the money-growth indicator also hinge on the assumed stability of the long-run income elasticity of money demand, which may shift after the introduction of the euro. The $P^{*}$ model breaks down without such stability (see Orphanides and Porter [28] and Rudebusch and Svensson [33]). Of course, the introduction of the euro might be associated with a shift in the long-run demand for euro which would make the $P^{*}$ model unreliable, possibly increasing the relative advantage of the output gap as an indicator for future inflation.

Thus, the first two caveats above apply in equal measure to all three indicators studied and do not provide any compelling reason to modify the conclusion that the information content in the real money gap is superior to that of the output gap and the money-growth indicator. The third caveat does not apply to the output gap and may hence provide a reason to modify the conclusions in the direction of increased relative indicator performance for the output gap. 


\section{References}

[1] Bernanke, Ben S., Thomas Laubach, Frederic S. Mishkin, and Adam S. Posen (1998), Inflation Targeting: Lessons from the International Experience, Princeton University Press.

[2] Bernanke, Ben S., and Ilian Mihov (1997), "What Does the Bundesbank Target?" European Economic Review 41, 1025-1054.

[3] Bernanke, Ben S. and Michael Woodford (1997), "Inflation Forecasts and Monetary Policy," Journal of Money, Credit, and Banking 29, 653-684.

[4] Browne, Frank X., Gabriel Fagan and Jerome Henry (1997), "Money Demand in EU Countries: A Survey," Staff Paper No. 7, European Monetary Institute.

[5] Bofinger, Peter (2000), "Inflation Targeting: Much Ado About Nothing New," Working Paper, University of Würzburg.

[6] Christiano, Lawrence C. (1989), " $P^{*}$ Is Not the Inflation Forecaster's Holy Grail," Federal Reserve Bank of Minneapolis Quarterly Review 13 (Fall 1989), 3-18.

[7] Clarida, Richard, Jordi Gali and Mark Gertler (1998), "Monetary Policy Rules in Practice: Some International Evidence," European Economic Review 42, 1033-1067.

[8] Clarida, Richard, Jordi Gali and Mark Gertler (1999), "The Science of Monetary Policy," Journal of Economic Literature 37, 1661-1707.

[9] Clarida, Richard, and Mark Gertler (1997), "How the Bundesbank Conducts Monetary Policy," in Romer, Christina, and David Romer, eds., Reducing Inflation: Motivation and Strategy, Chicago University Press.

[10] Coenen, Günter and Juan-Luis Vega (1999), "The Demand for M3 in the Euro Area," Working Paper No. 6, European Central Bank.

[11] Engle, Robert F. and Clive W.J. Granger (1987), "Co-integration and Error Correction: Representation, Estimation, and Testing," Econometrica 55, 251-276.

[12] European Central Bank (1998), "The Quantitative Reference Value for Monetary Growth," Press Release, December 1, 1998. 
[13] European Central Bank (1999a), "Euro Area Money Aggregates and Their Role in the Eurosystem, Monetary Policy Strategy," ECB Monthly Bulletin, February 1999, 29-46.

[14] European Central Bank (1999b), "The Stability-Oriented Monetary Policy Strategy of the Eurosystem," ECB Monthly Bulletin, January 1999, 39-50.

[15] Friedman, Benjamin M. (1975), "Targets, Instruments, and Indicators of Monetary Policy," Journal of Monetary Economics 1, 443-473.

[16] Fuhrer, Jeffrey C. (1995), "The Phillips Curve Is Alive and Well," New England Economic Review (March/April), 41-56.

[17] Fuhrer, Jeffrey C. (1997), "The (Un)Importance of Forward-Looking Behavior in Price Specifications," Journal of Money, Credit, and Banking 29, 338-350.

[18] Gerlach, Stefan and Frank Smets (1999), "Output Gaps and Monetary Policy in the EMU area," European Economic Review 43, 801-812.

[19] Hallman, Jeffrey J., Richard D. Porter, and David H. Small, (1991), "Is the Price Level Tied to the M2 Monetary Aggregate in the Long Run?," American Economic Review 81, $841-858$.

[20] Hausman, Jerry A. "Specification tests in Econometrics," Econometrica 46, 1251-1271.

[21] Issing, Otmar (1998), "The European Central Bank at the Eve of EMU," speech in London, November 26, 1998.

[22] Jahnke, Wilfried, and Hans-Eggert Reimers (1995), "The Transmission of Monetary Policy in the Econometric Model of the Deutsche Bundesbank for the German Economy," in Financial Structure and the Monetary Policy Transmission Mechanism, Bank for International Settlements, Basle, Switzerland.

[23] Kareken, John H., Thomas Muench, and Neil Wallace (1973), "Optimal Open Market Strategy: The Use of Information Variables," American Economic Review 63, 156-172.

[24] Laubach, Thomas, and Adam S. Posen (1997), Disciplined Discretion: Monetary Targeting in Germany and Switzerland, Essays in International Finance, No. 206, Princeton University. 
[25] Meltzer, Allan H. (1999), "The Transmission Process," in Deutsche Bundesbank, The Monetary Transmission Process: Recent Developments and Lessons for Europe, MacMillan, London, forthcoming.

[26] Nelson, Edward (2000), "Direct Effects of Base Money on Aggregate Demand: Theory and Evidence," Working Paper, Bank of England.

[27] Neumann, Manfred (1997), "Monetary Targeting in Germany," in Kuroda, Iwai, ed. Towards More Effective Monetary Policy, McMillan, London.

[28] Orphanides, Athanasios, and Richard Porter (1998), "P* Revisited: Money-Based Inflation Forecasts with a Changing Equilibrium Velocity," Journal of Economics and Business 52, $87-100$.

[29] Peersman, Gert, and Frank Smets (1999), "Uncertainty and the Taylor Rule in a Simple Model of the Euro-Area Economy," Working Paper.

[30] Roberts, John M. (1995), "New Keynesian Economics and the Phillips Curve," Journal of Money, Credit and Banking 27, 975-984.

[31] Rich, Georg (1997), "Monetary targets as a policy rule: Lessons from the Swiss experience," Journal of Monetary Economics 39, 113-141.

[32] Rudebusch, Glenn D., and Lars E.O. Svensson (1999a), "Policy Rules for Inflation Targeting," in John B. Taylor (ed.), Monetary Policy Rules, University of Chicago Press, 203-262.

[33] Rudebusch, Glenn D., and Lars E.O. Svensson (1999b), "Eurosystem Monetary Targeting: Lessons from U.S. Data," NBER Working Paper No. 7179.

[34] Svensson, Lars E.O. (1999a), "Inflation Targeting as a Monetary Policy Rule," Journal of Monetary Economics 43, 607-654.

[35] Svensson, Lars E.O. (1999b), "Monetary Policy Issues for the Eurosystem," CarnegieRochester Series on Public Policy 51-1, 79-136.

[36] Svensson, Lars E.O. (1999c), "Price Stability as a Target for Monetary Policy: Defining and Maintaining Price Stability," in Deutsche Bundesbank, The Monetary Transmission Process: Recent Developments and Lessons for Europe, MacMillan, London, forthcoming. 
[37] Svensson, Lars E.O. (2000), "Does the $P^{*}$ Model Provide Any Rationale for Monetary Targeting?" German Economic Review 1, 69-81.

[38] Svensson, Lars E.O. and Michael Woodford (1999), "Implementing Optimal Policy through Inflation-Forecast Targeting," Working Paper.

[39] Svensson, Lars E.O., and Michael Woodford (2000), "Indicator Variables for Optimal Policy," Working Paper.

[40] Swiss National Bank (1999), "Monetary Policy Decisions of the Swiss National Bank for 2000," Press Release, December 10, 1999.

[41] Taylor, John B. (1999), "The Robustness and Efficiency of Monetary Policy Rules as Guidelines for Interest Rate Setting by the European Central Bank," Journal of Monetary Economics $43,655-679$.

[42] Tödter, Karl-Heinz, and Hans-Eggert Reimers (1994), " $P$-Star as a Link between Money and Prices in Germany," Weltwirtschaftliches Archiv 130, 273-289.

[43] Tödter, Karl-Heinz, and Gerhard Ziebarth (1997), "Price Stability vs. Low Inflation in Germany: An Analysis of Costs and Benefits," NBER Working Paper No. 6150.

[44] Trecroci, Carmine, and Juan Luis Vega (2000), "The Information Content of M3 for Future Inflation," Working Paper No. 33, European Central Bank.

[45] von Hagen, Jürgen (1995), "Inflation and Monetary Targeting in Germany," in Leiderman, Leonardo, and Lars E.O. Svensson, eds. (1995), Inflation Targets, Centre of Economic Policy Research, London.

[46] Wesche, Katrin (1997), Die Geldnachfrage in Europa: Aggregationsprobleme und Empirie, Physica-Verlag, Heidelberg.

[47] Woodford, Michael (1999), "Price-Level Determination under Interest-Rate Rules," chapter 2 in Interest and Prices, book manuscript. 